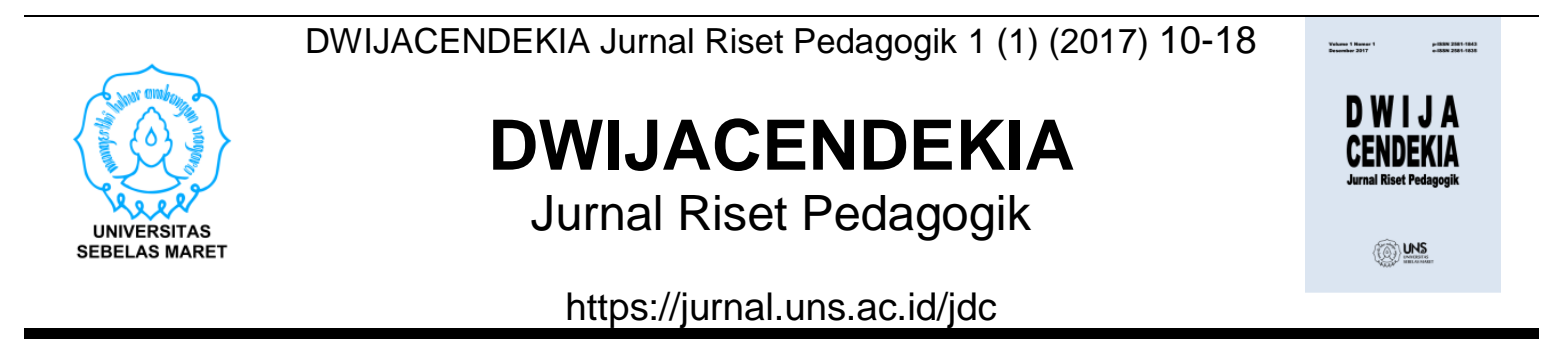

\title{
IMPLEMENTASI PEMBELAJARAN BAHASA INGGRIS SD BERBASIS BUDAYA DI YOGYAKARTA
}

\author{
Dinar Martia Azizah ${ }^{1}$, Anesa Surya ${ }^{2}$ \\ Universitas Sarjanawiyata Tamansiswa \\ Universitas Sebelas Maret
}

\section{Sejarah Artikel}

Diterima 18 Juli 2017

Disetujui 24 Juli 2017

Diterbitkan 1 Agustus 2017

\section{Kata Kunci}

bahasa Inggris, sekolah dasar, pendidikan berbasis budaya

\begin{abstract}
Abstrak
Penelitian ini mendeskripsikan perencanaan, pelaksanaan, penilaian, dan hambatan pembelajaran bahasa Inggris SD berbasis budaya di Yogyakarta. Hasil penelitian diharapkan menjadi bahan kajian untuk mengembangkan kebijakan pendidikan berbasis budaya di SD.Penelitian ini merupakan penelitian studi kasus. Subjek penelitian meliputi 5 SD Negeri berbasis budaya di Yogyakarta. Pengumpulan data menggunakan observasi partisipatif, wawancara semiterstruktur, dan dokumentasi. Teknik analisis data mengacu pada teknik analisis data Milles dan Huberman (2014). Teknik keabsahan data menggunakan teknik triangulasi metode dan sumber.Hasil penelitian menunjukkan bahwa silabus dan RPP yang digunakan kurang menunjukkan adanya integrasi budaya. Indikator dan tujuan pembelajaran masih bersifat umum. Integrasi budaya yang paling sering ditemukan dalam pembelajaran adalah penanaman nilai luhur. Hal tersebut dilakukan guru melalui contoh kalimat, teks, dialog, serta pembiasaan perilaku yang mencerminkan nilai luhur. Unsur budaya artefak dan adat istiadat tidak banyak ditemukan selama proses pembelajaran. Guru telah memahami hakikat penilaian berbasis budaya, namun belum menggunakan format penilaian yang sesuai dengan buku pedoman. Hambatan yang guru temukan dalam pembelajaran antara lain kurang meratanya bimbingan teknis pendidikan berbasis budaya, belum dicantumkannya contoh integrasi budaya dalam pembelajaran di buku pedoman, belum tersedianya buku teks dan media pembelajaran bahasa Inggris berbasis budaya, serta minimnya anggaran sekolah untuk menunjang pembelajaran bahasa Inggris.
\end{abstract}

Cara Mengutip

Azizah, D.M., Surya, Anesa (2017). Implementasi Pembelajaran Bahasa Inggris SD Berbasis Budaya di Yogyakarta. DWIJACENDEKIA Jurnal Riset Pedagogik, 1(1), 10-18. 


\section{PENDAHULUAN}

Bahasa Inggris merupakan bahasa asing yang dipelajari pada semua jenjang pendidikan. Pada jenjang Sekolah Dasar (SD), posisi bahasa Inggris berubah-ubah sesuai dengan kurikulum yang berlaku. Kurikulum 1994, 2004 dan 2006 menempatkan mata pelajaran bahasa Inggris sebagai muatan lokal. Pembelajaran bahasa Inggris menjadi kegiatan ekstrakurikuler pada kurikulum 2013. Kedudukan pembelajaran bahasa Inggris pada setiap perubahan kurikulum menegaskan bahwa pembelajaran tersebut dianggap penting untuk dipelajari sejak dini. Hal ini dipengaruhi anggapan bahwa pada usia emas, anak lebih mudah menguasai bahasa kedua atau bahasa asing khususnya dalam memahami tata bahasa, melatih pengucapan, dan menguasai kosakata.

Penguasaan bahasa Inggris pada usia emas anak dapat ditunjang oleh beberapa faktor, yakni metode pembelajaran, sarana dan prasarana, dan materi pembelajaran. Pada kenyataannya, masih dijumpai SD yang belum memaksimalkan faktorfaktor tersebut. Terdapat guru bahasa Inggris di SD mengajar dengan metode yang kurang tepat. Sarana dan prasana sekolah kurang memadai serta materi pembelajaran bahasa Inggris yang kurang kontekstual.

Bentuk kontekstulisasi materi pembelajaran dapat diwujudkan dengan mengintegrasikan budaya lokal dalam pembelajaran. Cara ini dianggap dapat membantu siswa belajar bahasa Inggris dengan mengkaitkan unsur kebudayaan yang telah dipahami siswa dengan materi baru. Pengintegrasian ini diharapkan dapat mewujudkan pembelajaran yang bermakna.

Di sisi lain, kontekstualisasi materi bukan hal yang mudah untuk direalisasikan dalam pembelajaran bahasa Inggris yang membawa unsur budaya asing yang berbeda dengan budaya lokal. Pengintegrasian materi dan budaya lokal menjadi tantangan tersendiri dalam pembelajaran bahasa Inggris. Berdasarkan permasalahan yang ditemukan dalam pembelajaran bahasa Inggris di SD berbasis budaya, peneliti tertarik untuk mendeskripsikan perencanaan, pelaksanaan, penilaian, dan hambatan pembelajaran bahasa Inggris SD berbasis budaya di Yogyakarta.

\section{METODE PENELITIAN}

Jenis penelitian ini merupakan studi kasus yang berfokus pada pencermatan terhadap fenomena sosial. Menurut Yin (2013: 13) studi kasus merupakan "an empirical inquiry that investigates a contemporary phenomenon within its real-life context, especially when the boundaries between phenomenon and context are not clearly evident". Pemilihan jenis penelitian studi kasus disebabkan tujuannya yang mendeskripsikan fenomena sosial, sesuai dengan tujuan penelitian ini. 
Penelitian ini melibatkan guru bahasa Inggris, kepala sekolah, dan siswa dari 5 SD berbasis budaya di Yogyakarta. Pemilihan SD ditentukan secara purposive. Cozby (2009: 140) menyatakan bahwa purposive sampling digunakan untuk "obtain a sample of people who meet some predetermined criterion". Kriteria yang digunakan dalam pemilihan SD adalah keunggulan dalam bidang seni dan budaya.

Teknik pengumpulan data yang akan digunakan pada penelitian ini meliputi teknik observasi, wawancara dan dokumentasi. Wawancara yang digunakan pada penelitian ini adalah wawancara semiterstruktur. Instrumen utama pada penelitian ini merupakan peneliti. Instrumen pengumpulan data pendukung lainnya dikumpulkan melalui lembar observasi, pedoman wawancara dan lembar analisis dokumentasi.
Teknik analisis data yang akan digunakan dalam penelitian ini berpedoman pada Miles, Huberman \& Saldana (2014: 3$)$ yang mengemukakan bahwa aktivitas dalam analisis data kualitatif dilakukan secara interaktif dan berlangsung secara terus menerus sampai tuntas. Aktivitas dalam analisis data, yaitu data condensation (kondensasi data), data display (penyajian data), dan conclusion drawing/verification (penarikan kesimpulan/verifikasi).

Teknik keabsahan data pada penelitian ini menggunakan teknik triangulasi metode dan sumber. Triangulasi metode diperoleh berdasarkan data pada observasi, wawancara dan dokumentasi. Triangulasi sumber diperoleh berdasarkan konfirmasi responden guru dan siswa kelas $V$.

\section{PEMBAHASAN}

\section{Perencanaan Pembelajaran Bahasa Inggris Kelas V SD Berbasis Budaya}

Silabus dan RPP merupakan bagian dari perencanaan pembelajaran. Silabus yang selama ini digunakan guru, dikembangkan melalui diskusi KKG. Silabus tersebut diakui guru masih memuat materi-materi yang umum. Selain itu, terdapat pula guru yang menyusun silabusnya sendiri. Silabus ini juga belum mencerminkan pembelajaran berbasis budaya karena guru belum mengetahui sebelumnya contoh silabus berbasis budaya serta cara mengembangkannya.
Silabus bahasa Inggris yang digunakan kelima SD berbasis budaya memiliki persamaan dalam standar kompetensi (SK) dan kompetensi dasar (KD) karena mengacu pada Peraturan Menteri No. 22 tahun 2006. Mengacu pada buku pedoman pelaksanaan pendidikan berbasis budaya (2014: 14) langkah pertama yang harus guru lakukan untuk mengintegrasikan budaya lokal adalah melakukan pemetaan terhadap standar isi. Hal ini dilakukan untuk melihat peluang diintegrasikannya unsur budaya. 
Hasil analisa terhadap SK dan KD pada silabus tersebut menunjukkan bahwa terdapat banyak peluang bagi guru untuk memasukkan unsur budaya. Peluang tersebut selanjutnya ditentukan oleh guru sendiri dalam melakukan pengembangan pembelajaran sesuai konteks sekolah masing-masing.

Peneliti juga melakukan analisa terhadap topik yang dimuat dalam silabus. Terdapat beberapa persamaan dan perbedaan topik dari masing-masing silabus. Topik yang sama dan dijumpai di semua silabus, antara lain introducing self, telling time, request, prohibition, asking and offering for help, asking and giving for permission, thanking, dan showing congratulations, and symphaty. Materi-materi tersebut sarat akan nilainilai luhur sehingga berpeluang juga untuk diitegrasikannya unsur budaya ke dalam pembelajaran.

Dalam pembuatan RPP, guru menyatakan bahwa telah mengacu pada silabus. Setelah itu guru berkonsultasi dengan kepala sekolah. Kepala sekolah memberikan saran yang beragam. Saran tersebut meliputi himbauan untuk melakukan integrasi dalam pembelajaran, mengacu pada buku pedoman, serta melakukan variasi dalam pembelajaran.

Guru mengakui bahwa integrasi budaya lokal dalam pembelajaran bahasa Inggris tidak mudah untuk dilakukan. Integrasi tersebut hanya dapat dilakukan pada topik-topik tertentu. Meskipun demikian, guru tetap berusaha memasukkan unsur budaya dalam pembelajaran. Unsur budaya yang paling sering guru adopsi dalam RPP adalah nilai-nilai luhur. Integrasi tersebut guru ciptakan melalui contoh kalimat dalam teks atau dialog.

Analisa terhadap lima RPP yang digunakan guru menunjukkan bahwa hanya sedikit RPP yang mencerminkan integrasi budaya. Indikator pencapaian kompetensi dan tujuan pembelajaran pada RPP telah menunjukkan integrasi budaya, khususnya nilai luhur. Materi pembelajaran dalam RPP juga berpeluang dalam terintegrasinya budaya lokal. Dalam kegiatan pembelajaran penanaman nilai luhur tercermin dalam kegiatan pendahuluan sampai kegiatan penutup. Aspek penilaian yang tertuang dalam RPP juga mencerminkan pendidikan pendidikan berbasis budaya karena menerapkan nilai-nilai luhur yang telah dipahami dalam konteks pembelajaran bahasa Inggris.

\section{Pelaksanaan Pembelajaran Bahasa Inggris Kelas V SD Berbasis Budaya}

Semua guru memahami hakikat dan tujuan pendidikan berbasis budaya. Dalam megintegrasikan unsur budaya dalam bahasa Inggris, sebagaian besar melalui penanaman nilai luhur, baik nilai yang dapat digali dalam kehidupan sehari-hari maupun pertahanan jati diri budaya lokal dalam proses pembelajaran bahasa asing. Selain itu, bentuk integrasi dilakukan melaui pengenalan artefak dan adat.

Guru memiliki cara yang beragam dalam mengintegrasikan budaya. Sebagian guru menggunakan teks dan dialog untuk memunculkan unsur budaya lokal. Dalam hal ini, guru memasukkan tema yang sesuai 
dengan kebudayaan, seperti candi Prambanan, dan candi Borobudur. Kompetensi pada kedua pembelajaran tersebut yakni memperkenalkan karya artefak berupa arsitektur.

Salah seorang guru mengungkapkan bahwa PLS (pembelajaran luar sekolah) ke Candi Borobudur merupakan upaya untuk mengintegrasikan budaya dalam pembelajaran. Dalam kegiatan tersebut, anak telah dibekali pengetahuan tentang borobudur melalui pembelajaran IPS sehingga sedikit banyak anak mengerti apa yang harus diungkapkan pada praktik speaking sederhana yang guru kembangkan. Kompetensi yang terdapat dalam kegiatan PLS adalah aktualisasi, maksudnya anak mampu menjelaskan karya artefak, dalam hal ini candi Borobudur.

Penanaman kesadaran antar budaya pernah guru lakukan melalui pembelajaran bahasa Inggris. Dalam mengajarkan materi greeting, guru mencari persamaan dan perbedaan dalam 3 bahasa, yakni bahasa Inggris, bahasa Indonesia, dan bahasa Jawa. Hal ini menyangkut konsep waktu dalam 3 bahasa tersebut yang dikaitkan dengan penggunaan sapaan yang tepat. Kompetensi pada pembelajaran ini adalah menanamkan nilai luhur.

Proses pembelajaran tidak dapat dipisahkan dari penggunaan media pembelajaran sumber belajar, dan sarana prasarana sekolah. Media yang sering digunakan guru adalah media gambar karena media berbasis budaya lokal untuk pembelajaran bahasa Inggris sulit didapatkan. Guru bahasa Inggris juga mengakui bahwa mereka tidak pernah memanfaatkan fasilitas kebudayaan yang ada di sekolahnya sebagai media pembelajaran karena tidak semua materi dapat diintegrasikan dengan fasilitas yang ada.

Keberadaan sumber belajar dianggap sebagai sesuatu yang penting dalam proses pembelajaran. Terdapat beberapa alasan yang dikemukakan, yaitu ketidakcocokan dengan materi yang akan diajarkan serta sekolah tidak tersedianya buku-buku terkait budaya dalam bahasa Inggris.

Dalam penggunaan sarana prasarana sekolah, guru juga mengakui jarang menggunakannya dalam pembelajaran karena membutuhkan waktu yang lama dalam proses persiapan. Meskipun demikian, terdapat guru yang memiliki pengalaman menggunakan sarana prasarana laptop dan LCD, untuk memutarkan video upacara adat untuk menstimulasi siswa memberikan tanggapan dalam bahasa Inggris.

Hasil wawancara, observasi, dan dokumentasi yang dilakukan peneliti, guru memiliki cara yang beragam dalam mengintegrasikan budaya lokal dalam pembelajaran bahasa Inggris. Secara keseluruhan, unsur budaya yang paling sering diintegrasikan adalah nilai luhur. Kompetensi yang dicapai meliputi mengenal, internalisasi, dan kreatif. Pada kompetensi mengenal, siswa dapat mengidentifikasi dan memahami nilai luhur. Pada kompetensi internalisasi, siswa dapat merasa bahagia berperilaku sesuai nilai luhur. Pada kompetensi kreatif, siswa mampu membiasakan berperilaku sesuai nilai luhur dan mengembangkan nilai luhur. Semua unsur budaya yang dimaksud, 
masuk dalam aspek spiritual, personal, sosial, nasionalisme.

Pada unsur budaya artefak, kompetesi yang dicapai adalah mengenal dan aktualiasasi. Pada kompetensi mengenal, siswa mampu mengenal karya artefak dalam lingkup cerita rakyat, arsitektur, pertunjukkan, dan boga. Pada kompetensi aktualiasasi, siswa dapat menjelaskan karya artefak.

Unsur budaya berupa adat merupakan unsur budaya yang jarang dimunculkan dalam pembelajaran bahasa Inggris. Dalam penelitian ini, hanya ditemukan satu kompetesi pada unsur budaya adat yakni mengenal. Kompetensi yang dimaksud adalah memahami adat DIY.

\section{Penilaian Pembelajaran Bahasa Inggris Kelas V SD Berbasis Budaya}

Guru, pada dasarnya telah memahami hakikat penilaian berbasis budaya. Guru tidak hanya menilai siswa dalam aspek akademik, tetapi juga sejauh mana siswa memahami budaya serta mengaplikasikannya dalam perilaku. $\mathrm{Di}$ sisi lain, semua guru belum menggunakan format penilaian sesuai dengan buku pedoman pelaksanaan pendidikan berbasis budaya. Guru menggunakan form penilaian yang telah mereka miliki sebelumnya.

\section{Hambatan Pembelajaran Bahasa Inggris Kelas V SD Berbasis Budaya}

Terdapat lima hambatan yang ditemukan dalam pelaksanaan pembelajaran bahasa Inggris yang terintegrasi budaya lokal sebagai berikut. a. Bimbingan teknis pendidikan berbasis budaya

Kegiatan ini merupakan bentuk sosialisasi pelaksanaan pendidikan berbasis budaya. Namun pada praktiknya dinilai belum merata. Kegiatan tersebut hanya diikuti oleh kepala sekolah serta beberapa guru dari SD yang ditunjuk. Beberapa guru lainnya belum pernah mendapat sosialisasi terkait pendidikan berbasis budaya. Di sisi lain, guru merasa bahwa pemahamannya terhadap budaya masih perlu untuk ditingkatkan melalui kegiatan sosialisasi atau seminar.

b. Pedoman pelaksanaan pendidikan berbasis budaya

Buku pedoman pelaksanaan pendidikan berbasis budaya belum memuat panduan cara mengintegrasikan budaya per mata pelajaran. Guru mengakui belum mendapatkan gambaran integrasi budaya dalam bahasa Inggris. Oleh karena itu, guru merasa kesulitan untuk mengembangkan perangkat pembelajaran berbasis budaya.

c. Buku teks bahasa Inggris berbasis budaya

Guru selama ini menggunakan buku teks sebagai salah satu acuan dalam pembelajaran. Di sisi lain, buku bahasa Inggris berbasis budaya sulit untuk didapatkan. Buku bahasa Inggris yang selama ini guru gunakan tidak memuat materi terkait kebudayaan. Guru mengakui bahwa untuk membuat materi sendiri bukanlah hal yang mudah. Guru merasa belum memiliki pemahaman yang cukup terhadap budaya, tuntutan administrasi yang beragam dan KBM yang padat, menyebabkan guru kurang memiliki waktu yang 
cukup dalam menyusun materi berbasis budaya.

d. Media pembelajaran bahasa Inggris berbasis budaya

Guru, selama ini hanya menggunakan media gambar karena dinilai lebih praktis dan mudah dalam membuatnya. Di samping itu, kepala sekolah mengakui bahwa media tersebut belum dapat mengoptimalkan pembelajaran bahasa Inggris yang terintegrasi dengan budaya lokal. $\mathrm{Hal}$ tersebut terkendala beban administrasi guru, waktu KBM dan kegiatan sekolah yang cukup padat.

e. Anggaran

Hambatan dari segi anggran untuk pengembangan pembelajaran bahasa Inggris disebabkan posisinya sebagai ekstrakurikuler. Anggaran lebih diutamakan untuk pengembangan mata pelajaran wajib di SD karena kondisi anggaran sekolah yang terbatas. Hal ini mempengaruhi pengadaan buku dan media pembelajaran bahasa Inggris.

\section{SIMPULAN}

Integrasi budaya dalam pembelajaran bahasa Inggris bukanlah hal yang mudah untuk dilakukan. Guru dituntut memiliki pemahaman terhadap budaya serta cara mengintegrasikannya dalam pembelajaran bahasa asing yang memiliki budaya berbeda dari budaya lokal. Di samping itu, tidak semua guru pernah mendapatkan bimbingan teknis pendidikan berbasis budaya. Guru bahasa Inggris SD juga belum dapat menggunakan buku pedoman pelaksanaan pendidikan berbasis budaya sebagai rujukan utama. Buku tersebut belum memuat secara rinci contoh pengembangan perangkat pembelajaran bahasa Inggris yang terintegrasi budaya lokal.

Ketidakmerataan bimbingan teknis pendidikan berbasis budaya serta belum dimuatnya contoh integrasi budaya dalam pembelajaran bahasa Inggris, menyebabkan guru belum mengembangkan silabus berbasis budaya secara optimal. Indikator dan tujuan pembelajaran masih bersifat umum, meskipun dalam SK dan KD yang digunakan guru memiliki peluang untuk diintegrasikannya budaya lokal.
Dengan demikian, pengembangan RPP yang mengacu pada silabus tersebut kurang mencerminkan pendidikan berbasis budaya.

Integrasi budaya dalam pembelajaran bahasa Inggris yang paling sering dilakukan guru adalah penanaman nilai luhur. Guru berusaha memperkenalkan dan membiasakan siswa untuk berperilaku sesuai nilainilai luhur. Pengenalan terhadap nilai luhur, biasanya guru lakukan dalam bentuk kalimat, teks, dan dialog. Dalam melakukan pembiasaan terhadap nilai luhur, guru selalu mengawali dan menutup pembelajaran dengan mengucapkan salam dan berdoa.

Integrasi budaya dalam pembelajaran bahasa Inggris juga dilakukan melalui pengenalan artefak dan adat istiadat. Kedua unsur budaya ini tidak banyak ditemukan selama proses pembelajaran. Hal ini disebabkan karena guru belum memiliki buku serta media pembelajaran bahasa Inggris berbasis budaya yang dapat membantu dalam pengembangan pembelajaran. 
Dalam proses penilaian, guru tidak hanya mengamati siswa dalam aspek akademik, tetapi juga sejauh mana siswa memahami budaya serta mengaplikasikannya dalam perilaku. Namun secara administratif, guru guru belum menggunakan format seperti yang ada pada buku pedoman pelaksanaan pendidikan berbasis budaya di SD.

Keberadaan buku teks dan media pembelajaran bahasa Inggris berbasis budaya masih jarang ditemukan. Proses pembuatannya pun tidak mudah. Selain itu, kedudukan bahasa Inggris di SD yang bukan merupakan mata pelajaran wajib, membuatnya tidak menjadi prioritas dari segi anggaran.

Berdasarkan kesimpulan di atas, peneliti memiliki sejumlah saran yang ditujukan kepada pihak-pihak berikut ini.

a. Dinas Pendidikan, Pemuda, dan Olahraga Provinsi DIY

Dinas Pendidikan, Pemuda, dan Olahraga diharapkan dapat menyelenggarakan kembali bimbingan teknis pendidikan berbasis budaya dan diberikan kepada semua guru secara merata. Buku pedoman pelaksanaan pendidikan berbasis budaya perlu untuk dikaji ulang, mengingat belum adanya contoh pengintegrasian budaya per mata pelajaran, termasuk bahasa Inggris. Dalam buku tersebut sebaiknya dicantumkan secara rinci langkahlangkah pengembangan semua perangkat pembelajaran berbasis budaya.

b. Kepala Sekolah SD Berbasis Budaya di Yogyakarta

Kepala sekolah diharapkan dapat menambah anggaran untuk menunjang kegiatan pengembangan pembelajaran bahasa Inggris yang terintegrasi dengan budaya lokal. Anggaran tersebut dapat ditujukan untuk pengadaan buku teks, media pembelajaran, dan kegiatan penunjang pembelajaran lainnya.

c. Peneliti lain Hasil penelitian ini menunjukkan bahwa masih terdapat banyak hambatan dalam pengintegrasian budaya lokal dalam pembelajaran bahasa Inggris. Hal ini dapat menjadi landasan bagi peneliti lain untuk melakukan penelitian yang bertujuan untuk mencari solusi atas hambatan tersebut, seperti pengembangan buku teks dan media pembelajaran bahasa Inggris berbasis budaya SD

\section{DAFTAR PUSTAKA}

Agus Wibowo dan Gunawan. (2015). Pendidikan Berbasis Kearifan Lokal di Sekolah : Konsep, Strategi, dan Implementasi. Yogyakarta: Pustaka Pelajar.

Cozby, Paul. C. (2009). Methods In Behavioral Research. New York: McGraw-Hill.
Miles, M.B. \& Huberman, A.M. (2014). Qualitative Data Analysis A Methods Sourcebook Third Edition. Los Angeles: Sage.

Pemerintah Daerah Istimewa Yogyakarta. (2011). Peraturan 
Dinar Martia Azizah, Anesa Surya/ DWIJACENDEKIA Jurnal Riset Pedagogik 1 (1) (2017) 10-18

Daerah No. 5 tahun 2011 tentang Pengelolaan dan Penyelenggaraan Pendidikan Tim Berbasis Budaya. Yogyakarta.

Scoot, Wendy A dan Lisbeth $\mathrm{H}$. Yterberg. (1990). Teaching English to Children. England: Longman.

Slattery, Mary dan Jane Willis. (2001). English for Primary Teachers.
Oxford: Oxford University Press.

Pengembang Pendidikan Berbasis Budaya di SD. (2014). Pedoman Pelaksanan Sekolah Berbasis Budaya. Yogyakarta: Disdikpora DIY.

Yin, R. K. (2014). Case Study Research: Design and Methods. 5th ed. California: SAGE Publications, Inc. 